\title{
The nation-state and international law: a reading from the Global
}

\section{South}

Luis Eslava** and Sundhya Pahuja ${ }^{\mathrm{b}}$

a Senior Lecturer, Kent Law School, University of Kent, Canterbury, England;

${ }^{b}$ Professor of Law, Melbourne Law School, The University of Melbourne, Melbourne, Australia

*Luis Eslava. University of Kent, Kent Law School, Canterbury, CT2 7NS, UK. Email: L.Eslava@kent.ac.uk (Corresponding author). Telephone: 0122782 (3344)

Sundhya Pahuja. University of Melbourne, Melbourne Law School, 185 Pelham Street, Carlton, Victoria 3053, Australia. Email: s.pahuja@unimelb.edu.au. Telephone: +61 3 83447102 .

\section{Acknowledgments}

We would like to thank Mimi Oorloff, current JD student at Melbourne Law School and editor of the Melbourne Journal of International Law, for her excellent research assistance.

\section{Funding}

N/A

\section{Notes on Contributors}

Luis Eslava is Senior Lecturer in International Law and Co-Director of the Centre for Critical International Law at Kent Law School, the University of Kent.

Sundhya Pahuja is Professor of International Law and Director of the Institute for International Law and the Humanities at the University of Melbourne.

\section{Disclosure statement}

No potential conflict of interest. 


\section{The nation-state and international law: a reading from the Global South}

In this article we re-describe the relationship between international law and the nation-state, reversing the usual imagined directionality of the flow between the two. At its most provocative, our argument is that rather than international law being a creation of the state, making the state is an ongoing project of international law. In the article, we draw on the example of the institutionalised project of development to illuminate the ways in which international law creates, and maintains nation-states, and then recirculates from a point 'within' them.

Keywords: nation-state; international law; development; post-colonial state; developmental state; new developmental state.

\section{Introduction}

A State is not a fact in the sense that a chair is a fact; it is a fact in the sense in which it may be said that a treaty is a fact: that is, a legal status attaching to a certain state of affairs by virtue of certain rules or practices. ${ }^{1}$

International interventions of all kinds - humanitarian, military, developmental, and financial - are usually predicated on the idea that a state, which has emerged from 'the people' 'within', is being 'assisted' from 'outside' - to develop, to overcome civil war, to govern itself better. Such interventions are neither imagined, nor constructed in law, as actions which impose and stabilise a legal form, 'the nation-state', from 'outside', disciplining it from 'within', to actualise and maintain that particular form. Indeed, the authority of international law, as well as the operation of the international legal order, rely on the twin myths which ground this reading: first, that states are independent juridical-institutional formations that come into being once they are formed in 'fact' and 
which are only later 'recognised' as a matter of international law; and second, that sovereign states come before a law which they have consensually created. ${ }^{2}$ A classic textbook statement reflecting this mythic grounding might be, '[i]n international law ... it is the states themselves that create the law and obey or disobey it'. ${ }^{3}$ And yet this predicate is not only mythic, but fictional; a fiction which conceals the world-making work of international law and institutions, a work now intensifying in both scope and violence.

In this article we re-describe the relationship between international law and the nation-state, reversing the imagined directionality of the flow that sequences nationstates as coming first and international law second. ${ }^{4}$ At its most provocative, our argument is that rather than international law being a creation of the state, making and remaking the state is a project of international law. We draw here on the example of the institutionalised project of development to illuminate the ways in which international law creates and maintains nation-states, and then recirculates from a point 'within' them. Understanding this process is particularly important when trying to make sense of the pasts and presents of the Global South, but is increasingly relevant to understanding reconfigurations of states in the North too.

In order to advance our argument, we offer a sketch of the intimate relationship between the international development project and nation-states over time. We begin in Part I with a brief outline of the shaping of international legal relations through the constitution of first colonial and then post-colonial states. In Part II, we describe how these (post)colonial states became 'developmental states' through, and in tandem with, the emergence of the international development project after World War II (WWII). In Part III, we describe the transitional moment of the 1980s and early 1990s during which 
these original, or 'old' developmental states were transformed into 'new developmental states'. This transformation took shape in response to the respective demands of first, what we know now as the Washington Consensus, and then of its successor, the PostWashington Consensus. In Part IV, we describe the shape and shaping of the new developmental state itself. In this section, we pay particular attention to how the making and re-making of these new developmental states is an ongoing project that increasingly shapes everyday life in the Global South. In the concluding section, we restate the argument, but gesture too, toward further shifts in practices of state making, and the increasing developmentalisation of the Global North.

Although the histories of the state, of international law, and of the development project that we offer here are for the most part, well known, our aim in this article is to read them together in order to show how the state has become the legal form through which the promises of international law, including the promise of development, ground themselves in the human and natural fabric of the world. In offering this re-description, we hope to draw out the practices which both shape and pathologise the state in the Global South - and increasingly in the Global North too - as well as to invite reflection on alternative ways of thinking about the study and the political practice of both statecraft and international law.

\section{International law and the (post)colonial state}

Since its relative triumph over rival forms of political association in seventeenth century Europe,${ }^{5}$ one of the main features of the nation-state has been bringing together, and giving jurisdictional coherence to, diverse geographical spaces and population groups. This has facilitated productive relations and the extraction of value from both humans in 
the form of labour and the natural environment in the form of resources. ${ }^{6}$ And yet this exercise of authority over 'national' territories and population has always been relational. For although the idea of an 'international' order was consolidated only towards the end of the eighteenth century, from their inception, nation-states worked not only to discipline the multiplicity of social groups and economic and legal understandings that existed 'within' their boundaries, but also to generate a supranational landscape - an international legal order - in which conflicts, trade, and overseas expansion could be negotiated. ${ }^{7}$ As Anne Orford has argued, 'constituting order' has been a central preoccupation of both nation-states and international law from the seventeenth century to the present day. ${ }^{8}$

Within the European context, the Ius Publicum Europaeum provided the framework for the emergence of states and the elements of proper international behaviour for the new nations..$^{9}$ As offspring of both the Enlightenment and European colonial expansion, the Ius Publicum Europaeum and the nation-state reflected the social transformations and Eurocentric cultural understandings prevailing at the time. Nation-states were, for example, the sites in which old monarchies and an expanding bourgeoisie managed to accommodate and multiply their interests under a new institutional logic and in new patterns of world making. ${ }^{10}$ The principles of rational administration of social and economic affairs that came to symbolise Europe's idea of civilization were also first put into practice within the context of European nationstates. ${ }^{11}$ When the Ius Publicum Europaeum travelled with European powers to the periphery (so becoming our current 'international law', instead of being just the 'public' law or law of encounter between European nations), ${ }^{12}$ it 'universalised' with itself, the jurisdictional practices by which the colonies could be ordered according to a Eurocentric national logic. 
Nineteenth century Swiss jurist, Johann Kaspar Bluntschli (1808-1881) exemplifies this universalising Eurocentric impulse in his work The Theory of the State. ${ }^{13}$ According to Bluntschli:

The highest idea of the State is beheld when the tendency of human nature to political society is considered, and the highest conceivable and possible development of this tendency is regarded as the political end of mankind. ${ }^{14}$

For Bluntschli the state was both a natural expression of the way political communities were organised, and the means through which these communities achieved their highest degree of material and spiritual perfection. In this story, '[w]hilst history explains the organic quality of the State', we learn from it too, 'that the State does not stand on the same grade with the lower organisms of plants and animals, but is of a higher kind'. ${ }^{15}$ As Bluntschli puts it, the state 'is a moral and spiritual organism, a great body which is capable of taking up into itself the feelings and thoughts of the nation, of uttering them in laws, and realising them in acts'. 16 'The glory and honour of the State have always elevated the heart of its sons, and animated them to sacrifices' ${ }^{17}$

Notwithstanding the elevation of the state by Bluntschli and many of his contemporaries, European expansion to the rest of the world was not accompanied by an immediate recognition of a right of non-European populations to organise themselves into independent nation-states. Colonial expansion operated, instead, through differential modes of rule, in which Europe persistently claimed predominance for itself vis-à-vis peripheral peoples and the 'colonial' states that it created. ${ }^{18}$ The duty to Christianise, the Standard of Civilization, and the White Man's Burden, accompanied by concepts such as terra nullius, and the rights to passage, to trade, to settle and to self- 
defense, together exemplify the jurisdictional constructions which brought colonial subjects and territories under the realm of European empires. ${ }^{19}$ These discursive and legal constructions established hierarchies first, between central and peripheral subjects, and later between modern and backward nation-states. And so by the end of the nineteenth century, after three centuries of intense colonial expansion across Africa, Asia, the Americas and the Pacific, it was no longer possible for non-European peoples, including for large and 'modern' polities like the Ottoman empire, to relate to Europe outside Europe's own parameters and categorisations. ${ }^{20}$ As Mark Mazower puts it, even though the Ottomans 'had in fact modernized rather quickly', 'European attitudes toward them had hardened faster still'.21

International law and international lawyers - which were also coalescing as both field and profession in the nineteenth century - were instrumental in Europe's reorganisation of the world. As Mazower has shown, during this period, international lawyers 'created a new language for European states ... to assess each other's claims to colonial territories' and for 'rescuing the mission of empire from its darker, dirtier side'. ${ }^{22}$ Based on their belief in the superiority of European civilization and their recognition of the existence of very different cultures and societies around the world (most of them considered to be 'barbaric' or even 'savage' by European standards), international lawyers concluded that European states had not only an inherent right, but also an historic responsibility 'to lead the world on the basis of a set of supposedly universal rules' ${ }^{23}$ The expansion of (European) economic interests, (European) culture, and (European) statehood formed the core of these 'universal' rules, rules that international lawyers in the South also began to embrace and adapt as their nations gained independence. ${ }^{24}$ Encapsulating this deployment of justifications and moral commitments within a landscape still plagued by imperial ambitions, Marti 
Koskenniemi has described the international law that emerged at this time as "the gentle civilizer of nations' ${ }^{25}$

As many critical international legal scholars have argued in recent years, this international ordering based on a 'dynamic of difference' ${ }^{\text {26 }}$ - between the apparent superiority of Europe and the partial or total inferiority of its others - was neither 'merely' a discursive construction nor a 'gentle' arrangement. ${ }^{27}$ This international order structured the way peripheral territories were administered and economically exploited, and how they were later integrated, for example, into the international institutional realm of the twentieth century, beginning with the League of Nations' Mandate System, and later the United Nations' Trusteeship Council. Through these international institutional frames, colonial possessions were understood according to a global ranking system - a 'universal standard of progress' - in which their level of subordination depended on how distant they were understood to be from the ideal embodied in the 'core' nations. ${ }^{28}$ In this context, statehood - recognition as an independent, selfdetermined nation-state - became the formal benchmark for assessing the moment when a colonial population moved from the condition of savagery or barbarism, to membership of the international family of nations.

The outcome of colonial subjects' struggles against their respective metropoles was, therefore, not the right to decide for themselves the mode in which they could organise their political communities and economic relations after independence. ${ }^{29}$ Instead of a right to 'self-definition', the outcome of the process of decolonisation was the principle of 'self-determination', which could be practiced only within the confines of the nation-state form, and often according to pre-established colonial boundaries that 
enclosed in single national formations highly disparate ethnic groups and incongruous geographical spaces. ${ }^{30}$

At the same time, the doctrine of self-determination brought post-colonial nation-states into being within the context of an already highly elaborated global political economy. From their inception then, post-colonial nation-states were not only forced to fit their social realities within a foreign institutional and administrative frame, the European nation-state, but also had to perform within a particular international economic system. This system was one in which they had already been conditioned to the position of producers of primary commodities, dependent on the industrial production of centre-nations, and in which they were already highly indebted to the global financial system which had lent them the resources to fight their wars of independence, set up new national bureaucracies and establish their armies. ${ }^{31}$

\section{The old developmental state}

Although 'conscripted' to the nation-state form, post-colonial and peripheral states were determined to refuse the predicament of their own history. ${ }^{32}$ So when the promise of development was issued in 1949 by United States President Truman, and the highly novel post-WWII international institutional apparatus began to embrace the idea of development, ${ }^{33}$ national leaders across the South took up the challenge to 'develop' their territories and populations. ${ }^{34}$ Their ambition was to board the train of modernity, and to demonstrate that their apparent inferiority vis-à-vis Northern nations was not related to their essential culture or race. Typically, this 'backwardness' was explained either to be an expression of their incipient economies (i.e. poor infrastructure, low 
productivity, lack of industries, and insufficient human capital), ${ }^{35}$ or related to the 'backward elements' within the state, such as indigenous and rural people, ${ }^{36}$ or some combination of both. ${ }^{37}$

At this point, the international order also became both highly nationalistic and state-centric, features that shaped the ambitions of leaders in the South. ${ }^{38}$ The understanding operative since the emergence of the state in the seventeenth century that states could always disappear entirely through invasion, war or treaty - changed drastically in 1945 with the UN Charter. ${ }^{39}$ That document accorded to statehood, 'a protected status under international law' ${ }^{40}$ In this new international legal order, it was clear that at least in formal terms, once statehood was achieved by nations, national leaders had enduring authority and a wide scope of action. ${ }^{41}$ 'International law' was confirmed, in turn, as the legal regime governing the relationships between states which were equal in law (de jure). Hence, in this understanding, international law underpinned a nation-state's own 'sovereign' law, and it operated as a nation-state's base law. This 'jurisdictional' grounding carried with it, however, significant limitations for any substantive redistribution of resources across nations. ${ }^{42}$ Its state-centrism also put paid to any serious contemplation regarding international law's potential to become the law of a world government - an idea that was present in many fora at the end of the nineteenth and beginning of the twentieth century. ${ }^{43}$

Acting on the basis of nation-states' newfound protections under international law after WWII, as well as their desire to develop and catch up with their 'modern' Northern peers, post-colonial national leaders began to launch National Development Plans, nation-wide education and health programs, and massive infrastructure and industrial projects. ${ }^{44}$ Large irrigation schemes, dams, refineries, bridges and power 
plants, as well as state-backed industrial initiatives, began to appear in countries as diverse as Kenya, India, South Korea, the Philippines, Peru, Egypt and Singapore. These schemes became emblems of the emergence of what we now identify as the 'developmental state'. ${ }^{45}$ The repeal of old statues from the colonial era, new national legislation in the areas of banking, administrative, labour and commercial law, and reforms to the judiciary and to legal education, also became fundamental instruments in the construction of nation-states dedicated to the enterprise of development. ${ }^{46}$

Although the concept of the developmental state is today often associated only with the success stories of East and South-East Asian countries (e.g. South Korea and Thailand), the union between the idea of development and strong nation-states was as intense in most other Southern states from the 1950s onwards, as it was in these emblematic places. Even many Latin American states, which had already accumulated a century or so of independent republican history, were in many ways reborn at this point, based on the idea of development and their own vision of how best to alight the train of modernity ${ }^{47}$ Key examples here include the Import Substitution Industrialization strategies of the 1950s, and later, from the mid-1960s, the dependency theory of development. ${ }^{48}$

However, the emergence of developmental states was not only marked by the difficulties of actualising a general European nation-state form in the economically constrained and culturally diverse South. Developmental states also amalgamated in their operation the sometimes conflicting, ideological and institutional trends that had marked the evolution of European nation-states over the previous three centuries. ${ }^{49}$ Thus the developmental state took shape as a commanding, highly centralised and reformist institution. These impulses reflected something like a Hobbesian call for 
strong sovereign governmental power in order to overcome the South's 'state of nature' ${ }^{50}$ W.W. Rostow's re-reading of global history through his famous 'stages of economic growth' came to offer a compelling technical solution of how to achieve this task, in particular for those states under the sphere of influence of the United States. Rostow's 'stages' theory offered a formula by which 'traditional societies', now called 'developing' countries', could achieve 'modernisation' via economic specialisation, capitalist accumulation and sustained consumption. ${ }^{51}$ In this way, for Southern states, development became a fitting framework of operation. It gave them the ability to organise and, most importantly, to present themselves as unitary entities within the international order that had emerged from WWII. The result of this process was that all public actions eventually became associated with the idea of development, fusing together international aspirations and domestic actions. ${ }^{52}$

From the 1950s to the mid-1980s, this marriage between the nation-state and development acquired a particularly important function in global affairs. During this time, UN membership grew from 51 to 159 members, most of whom were understood as 'underdeveloped'. The global polarisation generated by the Cold War neither threatened the role assigned to the figure of the nation-state in what was now known as the Third World, nor negated the call for the modernisation of Third World subjects. On the contrary, in both its capitalist and communist variants (although with different horizons in mind) the idea of development remained intimately linked to the figure of the nation-state and the need to culturally reshuffle Third World national citizenries. ${ }^{53}$ And so, in the Cold War charged environment and increasingly debt-laden international economic order, the Eurocentric, mythically Westphalian sovereign-state was thus consolidated as 'the agent of development' across the postcolonial world. ${ }^{54}$ 
As the second half of the twentieth century progressed, however, a generalised anxiety over the need to control territories and populations that had characterised the developmental state since its emergence, contributed to the rise of an infamous wave of dictatorships and authoritarian governments in the Americas, Africa, the Subcontinent and South-East Asia, often with the support of Northern powers. ${ }^{55}$ This anxiety was an expression and reflection of both the confluence of international development norms and institutions around the building of modern and developed nation-states, as well as the surfacing of intense internal resistance to development programmes. National governments, staffed by increasingly heavy-handed figures, became even more fixated on centrally generated, top-down development projects and on the extension of 'national' logics over the existing spatial and human landscape of their nations. The disastrous financial, social, and natural consequences that flowed from many of these heavy-handed initiatives were to act as triggers for even stronger resistance to the idea of development, by this point identified in many corners of the South as an expression of what Kwame Nkrumah had come to call 'neo-colonialism' ${ }^{56}$

\section{A moment of transition}

Although the interventionist policies operative until the early 1970s were generating high rates of private and public capital accumulation in most of the advanced capitalist countries and, to a lesser degree, across the Global South, 'the debt crisis' of the 1970s and 1980s severely undermined both the effectiveness of this model, and the esteem in which it was held in institutional terms ${ }^{57}$ Responding to the crisis, governments began to retreat from direct participation in the economy, shifting their energies to calibrated administrative actions and regulatory interventions. ${ }^{58}$ 
And so from the middle of the 1970s, and intensifying during the first half of the 1980s, the strong relationship between nation-building and the development project entered into crisis. Around this time, both the international commitment to the idea of Third World development and the enthusiasm for lending resources to states in the South receded, and were replaced by a series of strong criticisms and disciplinary measures directed toward them. National governments in the South were denounced by international institutions, as well as by new local elites, as unrepresentative of nationwide interests, and were urged to attend to the massively 'uneven' development within their national territories, a phenomena that in many instances had been created by earlier developmental interventions. These included alarming differences between urban and rural populations, men and women, and amongst ethnic groups. Centrally planned development programmes, public industries and private industries supported via public funds were also now denounced as economically inefficient, fiscally irresponsible, and incapable of generating the resources to service the accumulated foreign debt of states. In tandem with these accusations, governments in the Global South began to be accused for their poor human rights records and 'democratic deficits'. ${ }^{59}$

In this context, policies based on state contraction and market-based approaches gained pre-eminence, particularly within the programmes of structural adjustment imposed throughout the South by international institutions. These infamous reforms began with the IMF interventions throughout Latin America during the debt crisis of the 1980s. ${ }^{60}$ As a result of these interventions, governments of Argentina to Mexico - to be followed by many other countries across the South who hosted similar visits by international institutions - had to acquiesce to a systematic programme of privatisation, reduction of its public service, trade liberalisation and the shrinking of its social 
programmes. ${ }^{61}$ These policies, ideationally underpinned by neo-classical economics, were dictated by international institutions largely via conditionality agreements, and implemented by national elites. ${ }^{62}$ They aimed to overcome the assumed deficiencies associated with state economic and social interventionism, and to remake the conception of citizenship according to new principles of individual productivity and consumer satisfaction. These approaches were encapsulated in a series of doctrines that in retrospect became known as the 'Washington Consensus'. ${ }^{63}$ Such policies aimed to reshape state administration, reconfigure the relationship between state and market, and to promote a vision of citizens as economic agents with commercial initiative, economic judgment, and a duty of self-preservation.

The shift towards a more fluid understanding of the role of states and their populations in relation to market forces was accompanied by the dismissal of the central function that had been assigned to national governments in the development project. The dismantling of the USSR and the fall of the Berlin Wall were understood to confirm this need to move away from state-based development. This critical view of the state was epitomized in the World Bank's World Development Report: The Challenge of Development published in $1991 .{ }^{64}$ The initial lines of the report encapsulate the drift away from the state as the main force behind the idea of development:

The 1990s began with dramatic changes. ... Against the backdrop of these transitions, this ... Report links the historical debates that counseled policymakers in their past decisions, the lessons of experience, and the evolving thought on how best to proceed. One of the most valuable lessons relates to the interaction between the state and the market in fostering development. Experience shows that success in promoting economic growth and poverty reduction is most likely when governments complement markets; dramatic failures result when they conflict. ${ }^{65}$ 
As we can see from this extract, the World Bank had come to support a 'market-friendly approach' to development - one in which 'governments allow markets to function well, and in which governments concentrate their interventions on areas in which markets prove inadequate'. ${ }^{66}$ This new paradigm dramatically reshaped the landscape of development and quickly became a new orthodoxy in the field. In the early 1990s, a constrained view of the state and strong support for market-based solutions was embraced by international institutions and policy circles, and confirmed by sweeping governmental reforms and constitutional amendments in many South countries. ${ }^{67}$ In these new constitutions, trade liberalisation, privatisation, and strong supports for private property rights were enshrined alongside national commitments to protect human rights and foster democracy. ${ }^{68}$ This new approach to development also underpinned the emergence of new institutions and international discourses that further consolidated the idea of development through market-based solutions. The apparently axiomatic link between 'free trade' and 'development', for example, was mobilised in this period in the 'constitution' of the World Trade Organization (WTO). ${ }^{69}$

But by 1997, and responding to the apparent realisation that the market economy, like any other market, needs state support, the World Bank began to reconsider its position with respect to the role of the state in the development project. By this point it was starting to step back from the radically constrained view of the state it had embraced just a few years before. In its World Development Report for 1997, aptly titled The State in a Changing World, the Bank explored 'what the state should do, how it should do it, and how it can do it better in a rapidly changing world' ${ }^{70}$ The minimalist state position, the Bank now argued, was 
at odds with the evidence of the world's development success stories, be it the development of today's industrial economies in the nineteenth century or the postwar growth "miracles" of East Asia. Far from supporting a minimalist approach to the state, these examples have shown that development requires an effective state, one that plays a catalytic, facilitating role, encouraging and complementing the activities of private businesses and individuals. ${ }^{71}$

Based on this revised assessment, the World Bank suggested that (Southern) states still had a role to play in 'reducing poverty and fostering sustainable development' ${ }^{72}$ However, this new role was to be fulfilled by a 'new development state', a state that looked and behaved rather differently from the old developmental state with its commanding, centralised, and reformist impulses.

\section{The new developmental state}

After a long decade of structural reform policies, widespread social unrest, and the evident failures of many of the reforms, a new series of principles began to surface in national and international institutions and policy circles about the proper role of the state in the project of development. ${ }^{73}$ The consensus which emerged during the mid1990s suggested a more malleable view of the state. Instead of the state being imagined as an entity with a defined character and a pre-established role in the development process, the 'Post-Washington Consensus' recommended a more flexible relationship between the public and private sectors and the decentralisation of state development programmes. Both reorientations were accompanied by a greater use of law in 
development initiatives. These two new axioms and the instrumental use of law became the bedrock of the model that emerged during the late 1990s, and that still largely defines governmental action in the South today.

The reimagined relationship between the state and private sector in this "new developmental state' is reflected in the key technology of the 'public-private partnership'. Instead of an unconditional retreat from the economy, or the wholesale privatisation of public industries (strategies that are still being implemented in many places), the new approach is to set up legal frameworks, guiding principles and ownership arrangements that bring private capital and its imperatives to the terrain of public action. Such arrangements are common in the context of large infrastructure projects. In order to secure such deals, states in the developing world are newly attentive to being perceived as providing a 'good business climate' in which private capital can 'safely' flourish both independently and through its partnerships with a welcoming state. ${ }^{74}$

The reconfigured relationship between the state and private capital is also reflected in the creation of prescribed locales or 'zones' in which tax concessions, relaxed laws and special infrastructure are provided to investors to create local employment opportunities and expand the market for national products. ${ }^{75}$ At the same time, global corporations are being rehabilitated as developmental actors, through new requirements which seek to address the significant impacts of their activities through mechanisms such as community consultations which try to ensure that private capital brings at least some benefits to local communities. ${ }^{76}$ The discourse of Corporate Social Responsibility and the vocabulary of Corporate Citizenship also aim to recognise and expand the developmental impact of corporations. These vernaculars provide global 
corporations with legitimacy as 'development actors', as well as modalities through which to take an active role in the shaping of communities' present and futures. ${ }^{77}$

Woven together with this reconfigured relation between the state and private actors is the emergence of what has been called 'the entrepreneurial state' ${ }^{78}$ These are states which reassert their role in the economy, but do so operationally according to private managerial logics. ${ }^{79}$ This is increasingly common within the resource sector and in the provision of public services such as electricity, water, and sanitation. In the case of public utilities, this has had harsh effects, almost invariably increasing the cost of accessing public services, and embodying a stricter approach to the provision of services to informal settlements. ${ }^{80}$ In the particular case of newly public extractive industries, governments in the South are now becoming less tolerant of resistance by local communities and indigenous groups protesting the penetration of their territories. ${ }^{81}$

More recently still, the reconfigured relationship between private and public interests has found an additional expression in the citizenry of the new developmental state, now themselves imagined to be the agents of their own development. Abandoning the collective ideals that underpinned developmental thinking in the era of modernisation and the old developmental state, today governments address citizens as if individuals were sovereign over their own destinies. And if this is demonstrably not the case, because of low income, lack of education, or a marginal legal position, subjects are expected to acquire that sovereignty - the ability to stand on their own feet - with minimal amounts of state support. Examples include micro-credit schemes, cashtransfer, land titling programmes and neighbourhood legalisation schemes, as well as the moves to formalise informal vendors that have been widely implemented across the South in recent years. ${ }^{82}$ 
Behind these technocratic new developmental strategies lies an understanding of individual agency as existing beyond structural conditions. This view springs from several decades of constructing an image of individuals as being both oppressed by heavy national bureaucratic machineries, and as able to interact productively with market forces once they are provided with the necessary educational and institutional endowments. ${ }^{83}$ Amartya Sen's 'capabilities approach' to development has been influential in this regard. ${ }^{84}$ His view of individuals rests upon an understanding of equality as equality of opportunity. Such an understanding is grounded in an image of society 'organized as a competitive game', taking place upon a level playing field characterised by 'fair rules' ${ }^{85}$ And if these fair rules do not exist, it is assumed that they can be created, at least to a satisfactory level. This ideal level is, of course, a constantly shifting ground, raised or lowered according to the structural conditions dominating the economic possibilities of individual states. As a result, in a highly competitive global political economy that is constantly readjusting chains of production to the cheapest sources of labour, and where any progression in terms of poverty alleviation is outpaced by growing wealth disparity, the myth of a level playing field underpinned by fair rules becomes both a virtual policy goal and a disempowering political strategy.

The second operational imperative of the new developmental state, which feeds and supports the first, is the decentralisation of the state in territorial, fiscal, administrative and political terms. Often ignored by analysts, decentralisation has become an important force behind the restructuring of Third World states, and the wider global order, for the last two decades. ${ }^{86}$ Again marking an increased deployment of law as instrument, this has been accompanied by a plethora of legal reforms which reallocate responsibilities between central governments and new developmental actors. 
These reforms include national constitutional amendments which aim to recalibrate the responsibilities between national and local governments, non-governmental organisations, religious groups, private actors, and individuals themselves.

This recalibration has seen cities and municipalities throughout the South join the cast of new developmental actors, often bypassing national governments altogether and entering into direct partnerships with other entities, both international and national. Ileana Porras has called this process the 'internationalization of cities' to describe a shift that has involved the reallocation to local administrations, responsibilities previously understood as national and international, and a new role imagined for cities on both the national and international plane. ${ }^{87}$ These shifts have been cast by both international institutions and associations of local governments as emancipatory, because they move away from the highly centralised old developmental state, and are responsive to new models of capital accumulation that have rejected state based patterns and which connect local markets and consumers directly with the routines of transitional capital.

In this reconfiguration of the state, decentralisation has come to operate as a powerful political ideal. Within national and local governments, regional organisations, and at the highest levels of international institutions, there are mounting expectations about the potential of cities to operate as sites in which fairer, more economically intelligent and more humane models of development can be implemented. ${ }^{88}$ However, a focus on the putatively emancipatory dimension of decentralisation can serve to draw attention away from the more conservative frameworks which are shaping the actual functioning of local administrations. These frameworks, developed by international and national institutions and often keenly implemented by local elites, are exemplified by the World Bank's urban policy Cities in Transition ${ }^{89}$ which identifies the challenges the 
Bank understands to be facing Third World cities, and sets out the principles by interactions between the Bank and local administrations should be governed. Although the principles strive for more amenable cities, all action is consistently determined by the expectation that cities remain financially sustainable as discrete entities on one hand, and on the other, that all cities enter into a constant competition with both neighbouring cities and cities globally, in order to become socially and economically attractive to investment. The securitisation of cities by new community police forces, new surveillance technologies and private security companies is but one outcome of this new reality. ${ }^{90}$

As a result, local administrations in the Third World now have the constant anxiety of striking a balance between conflicting imperatives. So, for example, cities must provide universal access to drinking water within their jurisdictions at a time when water companies have been privatised, and when most of the city's residents cannot afford to pay their water bills. ${ }^{91}$ Such scenarios have become the day-to-day reality of local municipalities which face the widening set of responsibilities imposed upon them by their national administrations, international institutions, and the fluctuations of the international economic and financial order. Although powerful, the discourse of human rights, in this context, can only ameliorate the most extreme cases and is hardly ever able to ignite long lasting changes.

Thus the operative paradigm of decentralisation has come to replicate in the local context, the scenario that previously played out on the national level. However, this process of 'disciplining through decentralisation' unfolds in a setting marked by multiplying levels of governance and a proliferation of cross-enforcing legal regimes, such as a tight interaction between international norms, national administrative and 
fiscal laws, transnational private regulations, and local development and urban norms. These levels of governance and cross-enforcing legal regimes come directly to shape local populations and spaces. Understood in these terms, the operation of the international development project at a 'local' scale has not inaugurated a post-national moment. Instead, decentralisation has provided an opportunity to recalibrate the operation of a project of state-making through a more refined, but at the same time more expansive approach to population and territory.

Similarly, the new attention to the local does not imply that the international development project is finally making good its promises of world prosperity. Instead what we often see is an intensification of the contradictions that have accompanied the development enterprise since its inception. Residents may have benefitted from local administrations being more involved in providing services, and at least in theory, from the contraction of the democratic distance to the service provider. But as localised social life becomes more determined by international obligations and the economic order, poor rural areas, low-income municipalities, and informal urban settlements and their residents are being subjected to an increasing pressure to reshape themselves into the new parameters of the new developmental state and, perhaps most importantly, to a world economic order that increasingly treats them as surplus populations, totally irrelevant to the market. ${ }^{92}$

For all of these reasons, decentralisation has had critical impacts on both popular politics and on citizens' everyday relation with the state. With local administrations and many other actors more actively involved in local life, but lacking enough resources or interest, the process of decentralisation has often rearticulated itself, drawing established political and social networks into a new mesh of official or quasi-official 
politics and procedures and agencies. But this shift has not necessarily translated into more effective forms of social empowerment and welfare. ${ }^{93}$ Running alongside this, 'citizenship' - a longstanding category of national unification - is now under siege as decentralisation makes it difficult for people marginal to the official legal and economic order to find their place, or even a space for their claims to be heard. For many occupying the margins of the new geographies brought about by decentralisation, the new global attention to the local has meant the unrolling of what we might call 'a pedagogy of disenchantment', resulting from current forms of local planning and fiscal disciplining, disaggregated lines of responsibility amongst local, national and international levels of governance, and the proliferation of authorities representing such levels, alongside shrinking spaces for any meaningful contestation. ${ }^{94}$

The new developmental state thus promotes an image of the state as a molecular structure that actualises the expansion of the market and the flow of international capital across national boundaries facilitated through multiple scales of governance. In this arrangement, international norms and aspirations, and the tensions that they embody and transmit, have become thoroughly entangled with the everyday of the South. It is from this entanglement between international law and everyday life that the state is made and remade.

\section{Conclusions and further transitions?}

In the disciplinary mythology of international law, ${ }^{95}$ the 'modern' nation-state (understood as both sovereign and self-grounding) was born with the Peace of Westphalia in 1648, spread during the time of colonial expansion, and through the 
march of history, came to take proper shape in the independence of the Americas and the decolonisation of the rest of the Global South after the Second World War. ${ }^{96}$ In this mythology, 'international law' comes into being through inter-state practices that happen during norm producing moments, whether exceptional or routine. The 'historical' trajectory of international law 'itself', is also a story of progressive modernisation - its foundations shifting from Christianity to Secularity, its modality from comity to committee - and of transformation from European to 'Universal'. Once 'born' both into and apart from law, the story goes, all states may 'join' the system, and participate in law's creation and practice.

But as we have tried to show in this article, it is possible to understand the relation between nation-states and international law differently, particularly if we concentrate on how that relation has played out in the Global South from colonial times to today. To reorient our understanding, we need to see nation-states as social and cultural formations which are constantly trying to reshape disparate spaces and people into one - national - jurisdiction through administrative procedures, official imaginaries, and shared legal, financial and affective economies. Re-described in this way, the ostensibly 'historical' processes which both deliver nation-states into the world and ground the authority of international law, can be seen instead as ceaseless practices of what we might think of as nation-state-making, which are inter-national in both nature and orientation. The proliferation of nation-states across the South with decolonisation allowed a new model of international order to emerge. This order operates via a 'formal' parity amongst nation-states and a technicalised developmental discourse in which formerly imperial relations were transformed into a renovated vision of global multilateralism and cooperation. From this perspective, nation-states became the containers of 'intractable' social, political or economic problems. 
But allocating the responsibility and challenge of development to Southern states has not only marked the human and geographical spaces where the development project must be carried out. It has also allowed a clear separation of the realities of Third World nation-states from the larger international and historical context. Social, political, environmental and financial crises stemming from colonial pasts, failed development policies and debt accumulation can, in this way, be cast as technical problems belonging to individual nation-states and their national and now also local administrations. Importantly, this occurs while the promise of global development continues to enable international interventions that encourage a particular kind of global integration, [in which states are reshaped in ways which promote and protect the gains of the (transnational) few]. International law supports this process by facilitating, amongst other processes, 'the adoption of international economic laws which facilitate the globalisation of production and finance through creating and protecting global property rights, codifying the rights of transnational corporations, and limiting the economic autonomy of sovereign states' ${ }^{97}$ All of this occurs, as spaces and groups that resist the idea of development are suppressed and recast as being against 'national' interests or outside the inevitable laws of (capitalist) modernity.

But although these are practices usually now associated primarily with the idea of 'development', and particularly with the remediation of 'developing', 'failed', 'fragile' or 'transitional' states, ${ }^{98}$ nation-state-making is an ongoing activity for all states. States in the North are increasingly seeing themselves transformed into developmental states of sorts too. ${ }^{99}$ At the same time, the global extension of the developmental state-making project has happened with further shifts in the character of the states being made. Both the new developmental state, and the post-Washington 
Consensus in which it is grounded, are being reshaped by policies increasingly being reformulated by the new developmental powers and both traditional and new donors, from philanthropic capitalists to new evangelical churches. ${ }^{100} \mathrm{New}$ 'consensus' policies have also emerged expressed, for example, as the Beijing Consensus of 2004 and the Seoul Development Consensus of 2010. These shifts came in tandem with the lead up to the Global Financial Crisis (GFC) of 2008. Putatively 'sudden', but longer in the making, the GFC brought the state 'back in' in order to bear the regulatory and financial costs of the policies implemented over the preceding decades, which had given explicit support to the expansion of private interests. The GFC also propelled large amounts of capital from the economically deteriorated North, to Southern nations ${ }^{101}-$ which, after years of structural adjustment reform, were now well disciplined and open to market forces.

The even newer developmental state that has resulted from this process is one still geared towards market solutions, but one which bears an even larger responsibility in terms of sponsoring private initiatives, whilst offering further security through legal instruments and a regulatory environment characterised by 'law and order' measures. The global extension of the developmental state making project has had particularly (in)famous - and negative - consequences for those located in the South of the South, as well as in the Southern parts of the North, geographically and metaphorically speaking. Greece, Portugal, Spain and all of the poor, de-industrialised and often racialised and undocumented communities in the United Kingdom, the United States, and France for example, today all bear the burden of technologies of state making that were once reserved for the Global South. ${ }^{102}$ With that come amplifying processes of resistance, increasingly connected across such places. Popular neighbourhoods in Southern cities, scattered rural communities here and there, and indigenous peoples in 
each nation-state are speaking about this particular world that international law has helped to create, and seeking ways to transform them into something else. ${ }^{103}$ 


\section{Bibliography}

Alsop, Ruth, Mette Frost Bertelsen and Jeremy Holland. Empowerment in Practice: From Analysis to Implementation. Washington: World Bank, 2006.

Anghie, Antony. "Finding the Peripheries: Colonialism in Nineteenth-Century International Law." Chap. 2 in Imperialism, Sovereignty and the Making of International Law. Cambridge: Cambridge University Press, 2005.

Arendt, Hannah. "The Political Emancipation of the Bourgeoisie." Chap. 5 in The Origins of Totalitarianism. London: George Allen \& Unwin, 1958.

Asian Development Bank. Empowerment and Public Service Delivery in Developing Asia and the Pacific: Policy Report. Philippines: Asian Development Bank, 2013. Asian Development Bank. From the Ground Up: Case Studies in Community Empowerment. Philippines: Asian Development Bank, 2008.

Aust, Helmut Philipp. "Shining Cities on the Hill? The Global City, Climate Change, and International Law.” European Journal of International Law 26, no. 1 (2015): 255278.

Badie, Bertrand. The Imported State: The Westernization of the Political Order. Stanford: Stanford University Press, 2000.

Beard, Jennifer. The Political Economy of Desire: International Law, Development and the Nation State. Hoboken: Taylor and Francis, 2007.

Becker, Anne and Markus-Michael Müller. "The Securitization of Urban Space and the 'Rescue' of Downtown Mexico City: Vision and Practice." Latin American Perspectives 40, no. 2 (2013): 77-94. doi: 10.1177/0094582X12467762.

Becker Lorca, Arnulf. Mestizo International Law: A Global Intellectual History 18421933. Cambridge: Cambridge University Press, 2014.

Bilchitz, David. "Constitutionalism, the Global South, and Economic Justice." In Constitutionalism of the Global South: The Activist Tribunals of India, South Africa, and Colombia, edited by Daniel Bonilla Maldonado, 41-94. Cambridge: Cambridge University Press, 2013.

Birdsall, Nancy and Francis Fukuyama. "The Post-Washington Consensus:

Development after the Crisis.” Foreign Affairs 90, no. 2 (2011): 45-53.

Blank, Yishai. "The City and the World." Columbia Journal of Transnational Law 44, no. 3 (2006): 875-939. 
Blowfield, Michael. "Corporate Social Responsibility: Reinventing the Meaning of Development?." International Affairs 81, no. 3 (2005): 515-524. doi: 10.1111/j.14682346.2005.00466.x.

Bluntschli, Johann Kaspar. The Theory of the State. Kitchener: Batoche, 2000.

Boughton, James M. Silent Revolution: The International Monetary Fund 1979-1989. Washington: International Monetary Fund, 2001.

Braddick, Michael J. State Formation in Early Modern England, C.1550-1700.

Cambridge: Cambridge University Press, 2000.

Brenner, Neil and Nik Theodore, eds. Spaces of Neoliberalism: Urban Restructuring in North America and Western Europe. Oxford: Blackwell, 2002.

Brownlie, Ian. Principles of Public International Law. 5th ed. Oxford: Oxford University Press, 1998.

Campesi, Giuseppe. "Policing, Urban Poverty and Insecurity in Latin America: The Case of Mexico City and Buenos Aires." Theoretical Criminology 14, no. 4 (2010): 447-471. doi: 10.1177/1362480610366392.

Cardoso, Fernando Henrique and Enzo Faletto. Dependency and Development in Latin América. Berkeley: University of California Press, 1979.

Cass, Deborah Z. The Constitutionalization of the World Trade Organization: Legitimacy, Democracy, and Community in the International Trading System. Oxford: Oxford University Press, 2005.

Chatterjee, Partha. Empire and Nation: Selected Essays. New York: Columbia University Press, 2010.

Chatterjee, Partha. Nationalist Thought and the Colonial World: A Derivative Discourse. London: Zed Books, 1993.

Chimni, B.S. "Prolegomena to a Class Approach to International Law." European Journal of International Law 21, no. 1 (2010): 57-82.

Chimni, B.S. "Third World Approaches to International Law: A Manifesto." International Community Law Review 8, no. 1 (2006): 3-27.

Chimni, Bhupinder. "The Sen Conception of Development and Contemporary International Law Discourse: Some Parallels." The Law and Development Review 1, no. 1 (2008): 3-22. doi: 10.2202/1943-3867.1007.

Clarke, Gerard. "Agents of Transformation? Donors, Faith-Based Organisations and International Development.” Third World Quarterly 28, no. 1 (2007): 77-96. doi: 10.1080/01436590601081880. 
Craig, David and Douglas Porter. Development Beyond Neoliberalism?: Governance, Poverty Reduction and Political Economy. New York: Routledge, 2006.

Craven, Matthew. "Colonialism and Domination." In The Oxford Handbook of the History of International Law, edited by Bardo Fassbender and Anne Peters, 862-889. Oxford: Oxford University Press, 2012.

Crawford, James. Brownlie's Principles of Public International Law. 8th ed. Oxford: Oxford University Press, 2012.

Crawford, James. The Creation of States in International Law. 2nd ed. Oxford: Oxford University Press, 2006

Crawford, James. "Sovereignty As a Legal Value." In The Cambridge Companion to International Law, edited by James Crawford and Martti Koskenniemi, 117-133.

Cambridge: Cambridge University Press, 2012.

Dias, Maria Clara and Luis Eslava. "Horizons of Inclusion: Life Between Laws and Developments in Rio de Janeiro.” University of Miami Inter-American Law Review 44, no. 2 (2013): 177-218.

Domingo, Rafael. The New Global Law. Cambridge: Cambridge University Press, 2010 .

Drahos, Peter. "Developing Countries and International Intellectual Property StandardSetting." Journal of World Intellectual Property 5, no. 5 (2002): 767-789.

Escobar, Arturo. Encountering Development: The Making and Unmaking of the Third World. Princeton: Princeton University Press, 1995.

Escobar, Arturo. "Latin America at a Crossroads: Alternative Modernizations, PostLiberalism, or Post-Development?.” Cultural Studies 24, no. 1 (2010): 1-65.

Eslava, Luis. "Corporate Social Responsibility \& Development: A Knot of

Disempowerment.” Oñati Journal of Emergent Socio-Legal Studies 2, no. 2 (2008): 4371.

Eslava, Luis. 2014. “Dense Struggle.” Critical Legal Thinking. May 1. http://criticallegalthinking.com/2014/05/01/dense-struggle-violence-otherworldly/. Eslava, Luis. "The Developmental State: Independency, Dependency and the History of the South." In The Battle for International Law in the Decolonization Era, edited by J. von Bernstorff and P. Dann (eds), forthcoming.

Eslava, Luis. "Istanbul Vignettes: Observing the Everyday Operation of International Law." London Review of International Law 2, no. 1 (2014): 3-47. doi: 10.1093/lril/lru005. 
Eslava, Luis. Local Space, Global Life: The Everyday Operation of International Law and Development. Cambridge: Cambridge University Press, 2015.

Esquirol, Jorge L. "Titling and Untitled Housing in Panama City." Tennessee Journal of Law and Public Policy 4, no. 2 (2008): 243-302.

Esteva, Gustavo, Salvatore Babones and Philipp Babcicky, eds. The Future of Development: A Radical Manifesto. Bristol: Policy Press, 2013.

Evans, Malcolm D. International Law. $4^{\text {th }}$ ed. Oxford: Oxford University Press, 2014. Evans, Peter. Embedded Autonomy: States and Industrial Transformation. Princeton: Princeton University Press, 1995.

Farole, Thomas. Special Economic Zones in Africa: Comparing Performance and Learning from Global Experiences. Washington: The World Bank, 2011.

Fisch, Jörg. The Right of Self-Determination of Peoples: The Domestication of an Illusion. New York: Cambridge University Press, 2015.

Fisher, Jonathan. “'Does it Work?' - Work for Whom? Britain and Political Conditionality since the Cold War." World Development 75 (2015): 13-25.

Fitzpatrick, Peter. The Mythology of Modern Law. New York: Routledge, 1992. Foucault, Michel. “The Birth of Biopolitics.” In Ethics Subjectivity and Truth. Vol. 1 of The Essential Works of Michel Foucault 1954-1984, edited by Paul Rabinow, 73-80. New York: The New Press, 1997.

Foucault, Michel. “Sovereignty, Territory, and Population.” In Ethics Subjectivity and Truth. Vol. 1 of The Essential Works of Michel Foucault 1954-1984, edited by Paul Rabinow, 67-72. New York: The New Press, 1997.

Friedman, Jeremy. Shadow Cold War: The Sino-Soviet Competition for the Third World. North Carolina: University of North Carolina Press, 2015.

Frug, Gerald E. and David J. Barron. "International Local Government Law.” Urban Lawyer 38, no. 1 (2006): 1-62. doi:

Galeano, Eduardo. Open Veins of Latin America: Five Centuries of the Pillage of a Continent. Melbourne : Scribe, 2009.

Gonzalez, Carmen G. "Squatters, Pirates, and Entrepreneurs: Is Informality the Solution to the Urban Housing Crisis?." University of Miami Inter-American Law Review 40, no. 2 (2009): 239-259.

Gorman, Daniel. The Emergence of International Society in the 1920s. Cambridge: Cambridge University Press, 2012. 
Griffiths, Jesse and Konstantinos Todoulos. "Conditionally Yours: An Analysis of the Policy Conditions Attached to IMF Loans.” European Network on Debt and Development, 2014.

Gunder Frank, André. “The Development of Underdevelopment.” In Dependence and Underdevelopment: Latin America's Political Economy, edited by James D. Cockcroft, André Gunder Frank and Dale L. Johnson, 3-18. Garden City: Anchor Books, 1972. Hall, Stephen. Principles of International Law. $5^{\text {th }}$ ed. Chatswood: LexisNexis Butterworths, 2016.

Harvey, David. Spaces of Global Capitalism: Towards a Theory of Uneven Geographical Development. London: Verso, 2006.

Henkin, Louis. "International Law: Politics, Values and Functions: General Course on Public International Law.” Recueil des Cours 216 (1989): 9-416.

Hobbes, Thomas. The Leviathan. Online: Project Gutenberg, 2002.

Humphrey, Michael. "Violence and Urban Governance in Neoliberal Cities in Latin America." Paper presented at the People and Planet 2013 Conference: Transforming the Future, RMIT Global Cities Research Institute, Melbourne, July 2-4, 2013. James, Elliott, Kate McLoughlin and Ewan Rankin. "Cross-border Capital Flows since the Global Financial Crisis.” Bulletin (June 2014): 65-72.

Jessop, Bob. The State: Past, Present, Future. Cambridge: Polity Press, 2016. Johnson, Chalmers. MITI and the Japanese Miracle. Stanford: Stanford University Press, 1982.

Kennan, George F. American Diplomacy. Chicago: Chicago University Press, 1984. Kessides, Christine. Cities in Transition: World Bank Urban and Local Government Strategy. Washington: World Bank, 2000.

Koskenniemi, Marti. The Gentle Civilizer of Nations: The Rise and Fall of International Law 1870-1960. Cambridge: Cambridge University Press, 2001.

Lane, Philip R. "The European Sovereign Debt Crisis.” Journal of Economic Perspectives 26, no. 3 (2012): 49-68.

Leftwich, Adrian. "Bringing Politics Back In: Towards a Model of the Developmental State." Journal of Development Studies 31, no. 3 (1995): 400-427.

Li, Tania Murray. "Jobless Growth and Relative Surplus Populations.” Anthropology Today 29, no. 3 (2013): 1-2. doi: 10.1111/1467-8322.12026.

Li, Tania Murray. The Will to Improve: Governmentality, Development, and the Practice of Politics. Durham: Duke University Press, 2007. 
Lummis, Douglas. "Equality." In The Development Dictionary: A Guide to Knowledge as Power, edited by Wolfgang Sachs, 38-52. London: Zed, 1992.

Lustig, Nora and Nicholas Stern. "Broadening the Agenda for Poverty Reduction: Opportunity, Empowerment, Security." Finance \& Development 37, no. 4 (2000): 3-7. Lyons, Michael and Alison Brown. "Legal Pluralism and Development: Street-trade and Regulatory Reform in Tanzania.” Working Paper, London South Bank University, 2009.

Manji, Ambreena. "Whose Land Is It Anyway? The Failure of Land Reform in Kenya." Africa Research Institute, 2015.

Manning, Richard. “Will 'Emerging Donors' Change the Face of International Cooperation?" Development Policy Review 24, no. 4 (2006): 371-385. doi: 10.1111/j.1467-7679.2006.00330.x.

Mazower, Mark. Governing the World: The History of an Idea, 1815 to the Present. New York: The Penguin Press, 2012.

Mazower, Mark. No Enchanted Palace: The End of Empire and the Ideological Origins of the United Nations. Princeton: Princeton University Press, 2009. Mazzucato, Mariana. Entrepreneurial State: Debunking Public vs. Private Myths in Risk and Innovation. London: Anthem Press, 2013.

McCormick, Dorothy. “China \& India as Africa's New Donors: The Impact of Aid on Development." Review of African Political Economy 35, no. 115 (2008): 73-92. doi: $1080 / 03056240802011501$.

McEwan, Cheryl. Postcolonialism and Development. Hoboken: Taylor and Francis, 2008.

McGoey, Linsey. "The Philanthropic State: Market-State Hybrids in the Philanthrocapitalist Turn.” Third World Quarterly 35, no. 1 (2014): 109-125.

Milesi-Ferretti, Gian-Maria, Cédric Tille, Gianmarco I. P. Ottaviano and Morton O.

Ravn. "The Great Retrenchment: International Capital Flows during the Global Financial Crisis." Economic Policy 26, no. 66 (2011): 287-342.

Moore, Henrietta. 2015. “The Sustainable Development Goals: We're All Developing Countries Now." The Guardian, September 25.

https://www.theguardian.com/sustainable-business/2015/sep/25/sustainabledevelopment-goals-sdgs-inequality-developing-countries.

Narayan, Deepa. Empower and Poverty Reduction: A Sourcebook. Washington: World Bank, 2002. 
Nilsen, Alf Gunvald and Srila Roy. New Subaltern Politics: Reconceptualizing

Hegemony and Resistance in Contemporary India. New Delhi: Oxford University Press, 2015.

Nkrumah, Kwame. Neo-Colonialism: The Last Stage of Imperialism. New York: International Publishers, 1965.

Nyíri, Pál. "Enclaves of Improvement: Sovereignty and Developmentalism in the Special Zones of the China-Lao Borderlands." Comparative Studies in Society and History 54, no. 3 (2012): 533-562.

Obregón, Liliana. "Between Civilisation and Barbarism: Creole Interventions in International Law." Third World Quarterly 27, no. 5 (2006): 815-832. doi:

10.1080/01436590600780136.

Obregón Tarazona, Liliana. "The Civilized and the Uncivilized.” In The Oxford Handbook of the History of International Law, edited by Bardo Fassbender and Anne Peters, 917-942. Oxford: Oxford University Press, 2012.

Öniş, Ziya. "The Logic of the Developmental State." Comparative Politics 24, no. 1 (1991): 109-126. doi: 10.2307/422204.

Oppenheim, Lassa. Peace. Vol. 1 of International Law: A Treatise. London: Longmans, Green and Co, 1905.

Orford, Anne. "Constituting Order." In The Cambridge Companion to International Law, edited by James Crawford and Martti Koskenniemi, 271-289. Cambridge:

Cambridge University Press, 2012.

Pahuja, Sundhya. Decolonising International Law: Development, Economic Growth and the Politics of Universality. Cambridge: Cambridge University Press, 2011.

Pahuja, Sundhya. "Laws of Encounter: A Jurisdictional Account of International Law." London Review of International Law 1, no. 1 (2013): 63-98. doi: 10.1093/lril/1rt009. Pahuja, Sundhya. "Rights as Regulation: The Integration of Development and Human Rights." In The Intersection of Rights and Regulation: New Directions in Sociolegal Scholarship, edited by Bronwen Morgan, 167-192. Aldershot: Ashgate, 2007.

Pahuja, Sundhya. "Technologies of Empire: IMF Conditionality and the Reinscription of the North/South Divide." Leiden Journal of International Law 13, no. 4 (2000): 749813. doi: 10.1017/S0922156500000479.

Pahuja, Sundhya and Shaun McVeigh. "Rival Jurisdictions: The Promise and Loss of Sovereignty." In After Sovereignty: On the Question of Political Beginnings, edited by Charles Barbour and George Pavlich, 97-114. Oxon: Routledge, 2011. 
Pahuja, Sundhya and Anna Saunders. "Rival Worlds and the Place of the Corporation in International Law.” In The Battle for International Law in the Decolonization Era, edited by J. von Bernstorff and P. Dann (eds), forthcoming.

Parfitt, Rose. "Empire Des Nègres Blancs: The Hybridity of International Personality and the Abyssinia Crisis of 1935-36." Leiden Journal of International Law 24, no. 4 (2011): 849-872. doi: 10.1017/S0922156511000409.

Peet, Richard. Unholy Trinity: The IMF, World and WTO. 2nd ed. New York: Zed Books, 2009.

Porras, Ileana M. "The City and International Law: In Pursuit of Sustainable Development.” Fordham Urban Law Journal 36, no. 3 (2009): 537-601.

“Rafael Correa: Ecuador's Path, Interview.” New Left Review 77, (2012).

https://newleftreview.org/II/77/rafael-correa-ecuador-s-path.

Rist, Gilbert. The History of Development: From Western Origins to Global Faith. London: Zed Books, 2014.

Roberts, Bryan R. "Globalization and Latin American Cities.” International Journal of Urban and Regional Research 29, no. 1 (2005): 110-23.

Roberts, Bryan. "Urbanization, Decentralization and the Reorganization of Rural Life." In Rural Transformations and Development - China in Context: The Everyday Lives of Policies and People, edited by Norman Long, Ye Jingzhong and Wang Yihuan, 171190. Cheltenham: Edward Elgar, 2010.

Rodríguez-Garavito, César. "Toward a Sociology of the Global Rule of Law Field: Neoliberalism, Neoconstitutionalism, and the Contest over Judicial Reform in Latin America." In Lawyers and the Rule of Law in an Era of Globalization, edited by Yves Dezalay and Bryant Garth, 156-182. Oxon: Routledge, 2011.

Rostow, W.W. The Stages of Economic Growth: A Non-Communist Manifesto. $3^{\text {rd }}$ ed. Cambridge: Cambridge University Press, 1990.

Saad-Filho, Alfredo. "Social Policy for Neoliberalism: The Bolsa Família Programme in Brazil" Development and Change 46, no. 6 (2015): 1227-1252. doi: 10.1111/dech.12199.

Santos, Boaventure de Sousa. Toward a New Legal Common Sense: Law, Globalization, and Emancipation. London: Butterworths, 2002. Scarfi, Juan Pablo. The Hidden History of International Law in the Americas: Empire and Legal Networks. New York: Oxford University Press, 2017. 
Schmitt, Carl. The Nomos of the Earth in the International Law of the Jus Publicum Europaeum. New York: Telos Press, 2003.

Scott, David. Conscripts of Modernity: The Tragedy of Colonial Enlightenment.

Durham: Duke University Press, 2004.

Scott, James C. Seeing Like a State: How Certain Schemes to Improve the Human Condition Have Failed. New Haven: Yale University Press, 1998.

Shamsie, Yasmine. "Export Processing Zones: The Purported Glimmer in Haiti's Development Murk." Review of Political Economy 16, no. 4 (2009): 649-672.

Shaw, Malcolm. International Law. 7th ed. Cambridge: Cambridge University Press, 2014.

Slater, David. "Territorial Power and the Peripheral State: The Issue of Decentralization." Development and Change 20, no. 3 (1989): 501-531. doi: 10.1111/j.1467-7660.1989.tb00356.x.

Snyder, Sarah B. Human Rights Activism and the End of the Cold War. New York: Cambridge University Press, 2011.

Spruyt, Hendrik. The Sovereign State and Its Competitors: An Analysis of Systems Change. Princeton: Princeton University Press, 1994.

“The Visible Hand.” The Economist, January 21, 2012.

http://www.economist.com/node/21542931.

Thompson, Mark. "Late Industrialisers, Late Democratisers: Developmental States in the Asia-Pacific." Third World Quarterly 17, no. 4 (1996): 625-647. doi: $10.1080 / 01436599615290$.

Trubek, David. "Law and Development." In International Encyclopedia of the Social \& Behavioral Sciences, edited by Neil J. Smelser and Paul B. Baltes, 8443-8446. New York: Elsevier, 2001.

Trubek, David. The New Law and Development: A Critical Appraisal. Cambridge:

Cambridge University Press, 2010.

Vergara-Camus, Leandro. Land and Freedom: The MST, the Zapatistas, and Peasant Alternatives to Neoliberalism. London: Zed Books, 2014.

Vidal, John. 2016. “Are Gates and Rockefeller Using Their Influence to Set Agenda in Poor States?" Guardian, January 15.

Weber, Heloise. "The 'New Economy' and Social Risk: Banking on the Poor?.” Review of International Political Economy 11, no. 2 (2004): 356-386. 
Westad, Odd Arne. The Global Cold War: Third World Interventions and the Making of Our Times. Cambridge: Cambridge University Press, 2005.

Wilder, Gary. Freedom Time: Negritude, Decolonization, and the Future of the World. Durham: Duke University Press, 2015.

Williamson, John. "What Washington Means by Policy Reform.” Chap. 2 in Latin American Adjustment: How Much Has Happened?. Washington: Institute for International Economics, 1990.

Wilson, Japhy. "Fantasy Machine: Philanthrocapitalism as an Ideological Formation." Third World Quarterly 35, no. 7 (2014): 1144-1161. doi:

10.1080/01436597.2014.926102.

Woo-Cumings, Meredith. The Developmental State. Ithaca: Cornell University Press, 1999.

Woods, Ngaire. "Whose Aid? Whose Influence? China, Emerging Donors and the Silent Revolution in Development Assistance.” International Affairs 84, no. 6 (2008): 1205-1221. doi: 10.1111/j.1468-2346.2008.00765.x.

World Bank. Systems of Cities: Harnessing Urbanization for Growth \& Poverty Alleviation: The World Bank Urban \& Local Government Strategy. Washington: World Bank, 2009.

World Bank. World Development Report 1991: The Challenge of Development. Oxford: Oxford University Press, 1991.

World Bank. World Development Report 1996: From Plan to Market. Oxford: Oxford University Press, 1996.

World Bank. World Development Report 1997: The State in a Changing World. Oxford: Oxford University Press, 1997.

World Bank. World Development Report 2000/2001: Attacking Poverty. Oxford: Oxford University Press, 2000.

World Bank. "Urbanization Reviews." http://www.worldbank.org/en/topic/urbandevelopment/publication/urbanizationreviews. 


\section{Notes}

1. Crawford, The Creation of States, 5.

2. On the operation of recognition, in particular the declaratory theory of recognition, see Montevideo Convention, article 3. On the declaratory theory of recognition being an expression of modern international law, see Becker Lorca, Mestizo International Law, 305-352; Charter of the Organization of American States, article 13; ibid., 17-28. In regards to consent in international law, see Shaw, International Law, 9.

3. Shaw, International Law, 5. Lassa Oppenheim, Ian Brownlie and Louis Henkin define international law in a similar way. According to Oppenheim, '[s]ince the Law of Nations is based on the common consent of individual States, and not of individual human beings, States solely and exclusively are the subjects of International Law', Oppenheim, International Law: A Treatise, 18. For Brownlie, 'the general consent of states creates rules of general application', Brownlie, Principles of Public International Law, 2. And according to Henkin, 'State consent is the foundation of international law. The principle that law is binding on a State only by its consent remains an axiom of the political system, an implication of State autonomy', Henkin, General Course on Public International Law, 46.

4. See on the practice of re-description, Pahuja, "Laws of Encounter," 65.

5. Spruyt, The Sovereign State, 153-180. See also Braddick, State Formation.

6. Bob Jessop offers an important conceptualisation of the state along these lines as a 'social relation' grounded in Marx as well as later thinkers including Antonio Gramsci, Nicos Poulantzas, Michel

Foucault and Timothy Mitchell. See Jessop, The State: Past, Present, 1-91.

7. Jeremy Bentham being the first to use the concept of the 'international'. See Eslava, "Istanbul

Vignettes," 11.

8. Orford, "Constituting Order," 272.

9. Eslava, "Istanbul Vignettes," 11, 27.

10. Arendt, "The Political Emancipation," 124-134.

11. See e.g., Foucault, "The Birth of Biopolitics,"; and Foucault, "Security, Territory, and Population," 68-69.

12. Schmitt, The Nomos of the Earth, 227-232.

13. Bluntschli, The Theory of the State.

14. Ibid., 22.

15. Ibid., 27.

16. Ibid.

17. Ibid.

18. Young, The African Colonial State, 44.

19. See Anghie, "Finding the Peripheries"; Obregón Tarazona, "The Civilized and the Uncivilized"; and Craven, "Colonialism and Domination."

20. Mazower, Governing the World, 71-72.

21. Ibid.

22. Ibid., 73.

23. Ibid., 71.

24. Obregón, "Between Civilisation and Barbarism"; Becker Lorca, Mestizo International Law; Parfitt, "Empire des Nègres Blancs"; and Scarfi, The Hidden History.

25. Koskenniemi, The Gentle Civilizer of Nations. Martti Koskenniemi borrows the idea of international law as a 'gentle civilizer' from George Kennan. See Kennan, American Diplomacy, 53-54.

26. Anghie, Imperialism, Sovereignty, 4.

27. See McEwan, Postcolonialism and Development; Escobar, Encountering Development; and Beard, The Political Economy of Desire.

28. Chatterjee, Nationalist Thought, 1-35.

29. Wilder, Freedom Time, 241-259; and Pahuja and McVeigh, "Rival Jurisdictions," 104-106.

30. On the loss of the right to self-definition, see Rist, The History of Development, 79. The conservation of the old colonial boundaries was supported by the principle of utis possidetis iure, which was first implemented during the independence of Latin American states. See especially Fisch, The Right to SelfDetermination, 69-81, 206-207.

31. See e.g. Galeano, Open Veins of Latin America, 237-243.

32. On conscription and modernity, with all of its associated constructions, in the South, see Scott, Conscripts of Modernity.

33. This travelled through the UN, to the World Bank, passing through regional development banks and national aid agencies. 
34. Chatterjee, "Whose Imagined Community?" and "Development Planning and the Indian State" in Empire and Nation.

35. Pahuja, Decolonizing International Law, 54-59.

36. Eslava, “The Developmental State," 16.

37. Ibid.

38. See e.g. Mazower, No Enchanted Palace, 145-146.

39. Crawford, "Sovereignty As a Legal Value," 119-120.

40. Ibid., 120.

41. See especially, Charter of the United Nations, article 2(4), article 2(7).

42. Pahuja and McVeigh, "Rival Jurisdictions."

43. See on world government Gorman, The Emergence of International Society, 10-18, 309-320. This idea continues to surface in the present day in the form of the necessity of creating a new Global Law, a proposal that nonetheless struggles to shake off its imperial undertones. See for example Domingo, The New Global Law. See on a critical analysis of Global Law, Chimni, "Third World Approaches."

44. Chatterjee, "Development Planning and the Indian State" in Empire and Nation.

45. Eslava, "The Developmental State," 4-8. See also Escobar, Encountering Development; Li, The Will to Improve; Scott, Seeing Like a State; Woo-Cumings, The Developmental State; Evans, Embedded Autonomy; Öniş, "The Logic of the Developmental State"; Johnson, MITI and the Japanese Miracle; Thompson, "Late Industrialisers, Late Democratisers"; and Leftwich, "Bringing Politics Back In." 46. On the emergence and evolution of the Law and Development movement during this time, see: Trubek, The New Law, 74-81; and Trubek, "Law and Development."

47. Eslava, "The Developmental State," 9-18.

48. Key works on dependency theory and import substitution strategies include Gunder Frank, "The Development of Underdevelopment"; and Cardoso, Dependency and Development. For a discussion of the role of the Economic Commission for Latin America and the Caribbean (CEPAL) see Eslava, "The Developmental State," 23-27.

49. See especially, Badie, The Imported State, 91.

50. Hobbes, The Leviathan.

51. Rostow, Stages of Economic Growth, 17-35.

52. See Eslava, Local Space, Global Life.

53. See generally Friedman, Shadow Cold War, 60-100.

54. See Anghie, Imperialism, Sovereignty, 205. This consolidation is illustrated by a series of international normative commitments which extoll the nation-state as the most well protected entity in international law, while endowing it with the authority to control the sources and direction of the development process within each nation. Examples of these international norms include the UN Charter (1945), articles 2(4), 2(7); the Universal Declaration of Human Rights (1948) article 15; the Resolution on Permanent Sovereignty over Natural Resources (1962) articles 5, 7; the Declaration on the Establishment of a New International Economic Order (1974) articles 4(a), 4(e), 4(h); the Charter of Economic Rights and Duties of States (1975) chapter 1(a)-(d), articles 1, 2, 7; and the Declaration on the Right to Development (1986) article 2(3), 3(1), 4(1).

55. See generally Westad, The Global Cold War.

56. Nkrumah, Neo-Colonialism: The Last Stage, 239-354.

57. Peet, Unholy Trinity, 78-123.

58. See Harvey, Spaces of Global Capitalism, 11-25.

59. Snyder, Human Rights Activism.

60. For an institutional review of this period, see e.g., Boughton, Silent Revolution. For a critical review of this period, see especially, Peet, Unholy Trinity, 85-87.

61. Peet, Unholy Trinity, 112.

62. Pahuja, “Technologies of Empire”; Fisher, “'Does it Work?' - Work for Whom?”; and Griffiths and Todoulos, "Conditionally Yours."

63. The term 'Washington Consensus' was first coined by economist John Williamson in 1989.

Williamson, "What Washington Means by Policy Reform".

64. See also World Bank, World Development Report 1996.

65. World Bank, World Development Report 1991, iii.

66. Ibid.

67. Rodríguez-Garavito, “Toward a Sociology," 160-162; and Santos, Toward a New Legal, 439-95.

68. On the constitutionalisation of neoliberalism in the South see Bilchitz, "Constitutionalism, the Global South"; and Rodríguez-Garavito, "Toward a Sociology," 164-167. 
69. Cass, Constitutionalization of World Trade Organization, 243-244. On developing countries and the WTO, see Drahos, "Developing Countries and International Intellectual Property," 788-789. Pahuja and Saunders, "Rival Worlds."

70. World Bank, World Development Report 1997, iii.

71. Ibid.

72. Ibid., 17.

73. See Birdsall and Fukuyama, "The Post-Washington Consensus"; and Craig and Porter, Development Beyond Neoliberalism?.

74. Harvey, Spaces of Global Capitalism, 25.

75. These go by various names including Free Trade Zones, Economic Integration Zones, Special Reform Zones, Exporting Processing Zones and Business and Industrial Parks. For examples of the emergence and operation of these new jurisdictions see Shamsie, "Export Processing Zones"; Farole, Special Economic Zones in Africa; and Nyíri, "Enclaves of Improvement."

76. Pahuja and Saunders, "Rival Worlds."

77. Eslava, "Corporate Social Responsibility \& Development," 43-56; and Blowfield, "Corporate Social Responsibility," 516-519.

78. See for example, Mazzucato, The Entrepreneurial State.

79. "The Visible Hand." The Economist.

80. Eslava, Local Space, Global Life, 175-218.

81. See for example interview with Rafael Correa, Ex-President of Ecuador, in the New Left Review. "Rafael Correa: Ecuador's Path, Interview." New Left Review. See also Escobar, "Latin America at a Crossroads".

82. Esquirol, "Titling and Untitled Housing"; Manji, "Whose Land Is It Anyway?"; Weber, "The 'New Economy' and Social Risk"; Saad-Filho, "Social Policy for Neoliberalism”; and Lyons and Brown, "Legal Pluralism and Development."

83. World Bank, World Development Report 2000/2001, 99-134; Narayan, Empowerment and Poverty Reduction; Alsop, Bertelsen and Holland, Empowerment in Practice; Asian Development Bank,

Empowerment and Public Service Delivery; Asian Development Bank, From the Ground Up; and Lustig and Stern, Broadening Agenda for Poverty Reduction.

84. Chimni, "The Sen Conception of Development"; and Pahuja, "Rights as Regulation," 175-181.

85. Lummis, "Equality," 43.

86. See Eslava, Local Space, Global Life. On an early assessment of decentralisation, see Slater, "Territorial Power and the Peripheral State". See also, Brenner and Theodore, Spaces of Neoliberalism; and Craig and Porter, Development Beyond Neoliberalism?.

87. Porras, "The City and International Law." See also, Blank, "The City and the World"; and Frug and Barron, "International Local Government Law."

88. Aust, "Shining Cities on the Hill?," 255-261.

89. See especially, World Bank, Cities in Transition. See also, World Bank, Systems of Cities. See on country specific reports based on these guidelines for local development: World Bank, "Urbanization Reviews."

90. Dias and Eslava, "Horizons of Inclusion," 185; Becker and Müller, "The Rescue of Downtown Mexico," 78; Humphrey, "Violence and Urban Governance"; and Campesi, "Policing, Urban Poverty," 466.

91. See Gonzales, "Squatters, Pirates, and Entrepreneurs," 249-250.

92. See for example, Li, "Jobless Growth Surplus Populations".

93. Roberts, "Globalization and Latin American Cities," 118-119; and Roberts, "Urbanization,

Decentralization," 184-187.

94. Eslava, "Dense Struggle."

95. Fitzpatrick, Mythology of Modern Law.

96. Crawford, Brownlie's Principles, 3-19; Hall, Principles of International Law, 1-10; and Evans, International Law, 11-24.

97. Chimni, "Prolegomena to a Class Approach," 71-72.

98. Fund for Peace. "Fragile States Index." Accessed August 15, 2017. http://fundforpeace.org/fsi/ 99. Moore, "The Sustainable Development Goals."

100. The new developmental powers have been classified in recent years under the categories of 'BRICS' (Brazil, Russia, India, China and South Africa) and 'CIVETS' (Colombia, Indonesia, Vietnam, Egypt, Turkey, and South Africa), but the adequacy of these umbrella terms has been contested rapidly, and the sources of funding are being rapidly displaced by private philanthro-capitalism. See on new donors: Woods, "Whose Aid? Whose Influence"; McCormick, "China India Africa's New Donors"; Manning, 
"Will 'Emerging Donors' Change"; Clarke, "Agents of Transformation?"; Vidal, "Gates and Rockefeller Using Influence"; Wilson, "Fantasy Machine"; and McGoey, "The Philanthropic State."

101. Milesi-Ferretti and Tille, "The Great Retrenchment": and James, McLoughlin and Rankin, "Crossborder Capital Flows."

102. Lane, "The European Sovereign Debt Crisis," 62-65;

103. For a general discussion about the crucial role of resistance to development, see especially, Esteva, Babones and Babcicky, The Future of Development, 136-143. See also Vergara-Camus, Land and Freedom; and Nilsen and Roy, New Subaltern Politics. 